\title{
Book Review: Global inequality. A new approach for the age of globalization
}

\author{
Ana Bela Nunes \\ ISEG - Lisbon School of Economics and Management, \\ Universidade de Lisboa, Lisbon, Portugal
}

by Branko Milanovic

Cambridge, Massachusetts

The Belknap Press

2016

p. 320

ISBN: 10 : 067473713X

ISBN: 13 : 978-0674737136

Review DOI 10.1108/EJMS-09-2020-003

Branko Milanovic's book on global inequality is remarkable and interesting for a wideranging educated audience (which is not just restricted to scholarly academics of differing disciplines), for the reasons that are implicit in the basic concept of the book. It begins with a survey of an update of global inequality today, and then commences an analysis of inequality from a historical perspective - first during the period of modern economic growth, and then further back, to pre-modern societies - to support the presentation of some innovative theoretical and methodological approaches. It returns to the present to discuss possible forecasts of inequality in the (more or less near) future, and the consequences of this inequality for the economic, social and political systems, using the analytic apparatus previously introduced. Furthermore, it also presents some items of an agenda designed to face up to the recent increasing trend in global inequality.

The analysis is based on a large amount of new data from new sources, namely, household surveys from China and other highly populated Asian emerging economies, whose availability has increased significantly since 1980s. However, most of the conceptual, theoretical, and methodological issues are explained in excursuses, although the updated results are displayed in a very appealing way, with suggestive figures that facilitate an easy perception of the long-term trends in global inequality, including the effects of the recent financial crisis. This analysis is concise, but rigorous, decomposing global inequality into inequality among countries (the "location" component) and inequality within countries (the "class" component), using a variety of disciplinary tools and theories, ranging from political science and sociology to economics.

The first chapter starts by focusing on the more recent period and presents a sociological assessment of the income groups that have benefited from globalisation (with higher relative gains in terms of real per capita income), which the author calls the "global middle

(C) Ana Bela Nunes. Published in European Journal of Management Studies. Published by Emerald Publishing Limited. This article is published under the Creative Commons Attribution (CC BY 4.0) licence. Anyone may reproduce, distribute, translate and create derivative works of this article (for both commercial and non-commercial purposes), subject to full attribution to the original publication and authors. The full terms of this licence may be seen at http://creativecommons.org/licences/by/4.0/legalcode

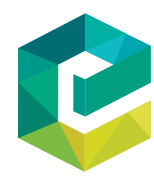

European Journal of Management Studies No. 1,2020 Emerald Publishing Limited 2183-4172 
EJMS

25,1

46

class", located in the median of the global income distribution (corresponding to the middle classes of the emerging, highly populated Asian economies), and the "global plutocrats", who are the global top $1 \%$ (corresponding to a few hundred families located mainly in highly developed economies). The recent financial crisis has exacerbated this trend.

The historical perspective becomes decisive in the design of an original general theory to explain the cyclic, very long-term trends in inequality, as a means to overcome the "dissatisfaction" with the Kuznets hypothesis for explaining the recent increase in inequality within countries, and also the dissatisfaction with Piketty's theory for explaining the increase in inequality in the 18th and 19th centuries. The historical perspective is displayed over three different time spans: the present (the past 25 years), the modern economic growth period ("the post-industrial period") and returning to include pre-industrial societies. Although it may be appealing, this attempt to create a general theory to encapsulate pre-industrial and postindustrial societies may offend the (historical) sensitivity of those who consider that different apparatuses are required to deal with very different social, economic, and political structures. The general explanation for Kuznets' waves (or cycles), which depict the pattern of changes in inequality over time, relies on economic, sociological, political, demographic, and institutional factors - which are grouped into "malign" and "benign" forces operating in pre-modern societies (with a "stagnant mean income"), as well as in modern societies (with a "rising mean income") - which allows for a very rich explanatory theory, which integrated different disciplinary approaches and topics, as mentioned above.

The last chapters elaborate on possible future trends and on an agenda to reduce global inequality, and its two main components (What next? Ten short reflections on the future of income inequality and globalization). Some of the policies suggested are quite controversial, albeit well-argued, and they include: to reduce inequality in rich welfare states through policies to achieve lower inequality of market (before taxes) income, namely, equalising endowments, high inheritance taxes to equalise capital endowment and a state-funded education to equalise access to high-quality education (instead of using increased taxation, social transfers, hyperinflation, nationalisation of property and wars); to reduce inequality among countries through a more liberal attitude towards immigration in highly-developed economies, whilst introducing different, intermediate degrees of citizenship. In this context, topics related to the effects of global inequality are also covered. The author considers that capitalism, as an economic system, will survive, but, as far as the impact of inequality on democracy is concerned, the author supports that the phenomena of populism and nativism raises a problem of the trade-off between globalisation and democracy, and he supports the position that although democracy is formally in place (with free elections and freedom of expression), it is really diminished, and that inequality may be a relevant topic when it comes to tackling ecological issues.

\section{Corresponding author}

Ana Bela Nunes can be contacted at: abnunes@iseg.ulisboa.pt

For instructions on how to order reprints of this article, please visit our website:

www.emeraldgrouppublishing.com/licensing/reprints.htm

Or contact us for further details: permissions@emeraldinsight.com 